\title{
First surgical care of Mexican children in the nineteenth century
}

\author{
Primicias de la atención quirúrgica de los niños mexicanos en el siglo XIX \\ Manuel Antonio Baeza-Bacab* \\ Inter-institutional Unit of Clinical and Epidemiological Research, Faculty of Medicine, Universidad Autónoma de Yucatán, Mérida, Yucatán, Mexico
}

\begin{abstract}
Here, two papers are presented, which constitute the first reports of surgical procedures in Mexican children performed at the 19th century. The two publications refer to surgical operations for the extraction of bladder stones. At that time, there was no anesthesia, so part of the description alludes to the suffering of the patients and the operative difficulties. The first case, is referred to as a lithotomy in a 17-year-old girl, performed by surgeon José Victoriano Guerrero in Guadalajara in 1822. The publication is not an academic report, but a pamphlet written as a gift to Emperor Augustin I to celebrate his ascension to the throne. The second work, is a lateral lithotomy in a 5-year-old boy, published by Dr. Luis Jecker in the first issue of the Periódico de la Academia de Medicina de Mégico in 1836.
\end{abstract}

KEY WORDS: Cystostomy. 19th century history. Calculi of urinary bladder. Children. Mexico.

\section{Resumen}

Se presentan dos trabajos que constituyen los primeros informes de procedimientos quirúrgicos en niños mexicanos en el siglo XIX. Las dos publicaciones se refieren a operaciones para la extracción de cálculos vesicales. En ese tiempo no existía anestesia, por lo que parte de la descripción incluye el sufrimiento de los pacientes y las dificultades operatorias. El primer caso está referido como una litotomía en una joven de 17 años, operada por el cirujano José Victoriano Guerrero en Guadalajara en 1822. La publicación no constituye un informe académico, sino un folleto escrito como un obsequio para el emperador Agustín I para celebrar su ascensión al trono. El segundo trabajo es una talla lateral en un niño de 5 años edad, publicado por el doctor Luis Jecker en el primer número del Periódico de la Academia de Medicina de Mégico en 1836.

PALABRAS CLAVE: Cistostomía. Historia siglo XIX. Cálculo vesical. Niños. México.

\section{Introduction}

Prior to the $19^{\text {th }}$ century, publications about surgical procedures in children were anecdotal. Among these, an alleged extraction of a bladder stone observed by
Cristóbal Méndez around $1529^{1}$ and the care provided by Pedro Arias de Benavides to a boy with a head injury in 1561 stand out ${ }^{2}$. Apparently, after these citations, there are no reports of other procedures until the mid$19^{\text {th }}$ century, when reports begin to multiply, probably due to the development of anesthesia and antisepsis ${ }^{3}$.

\section{Correspondence:}

*Manuel Antonio Baeza Bacab

Avenida Itzaes 498 por 59-A

Col. Centro 


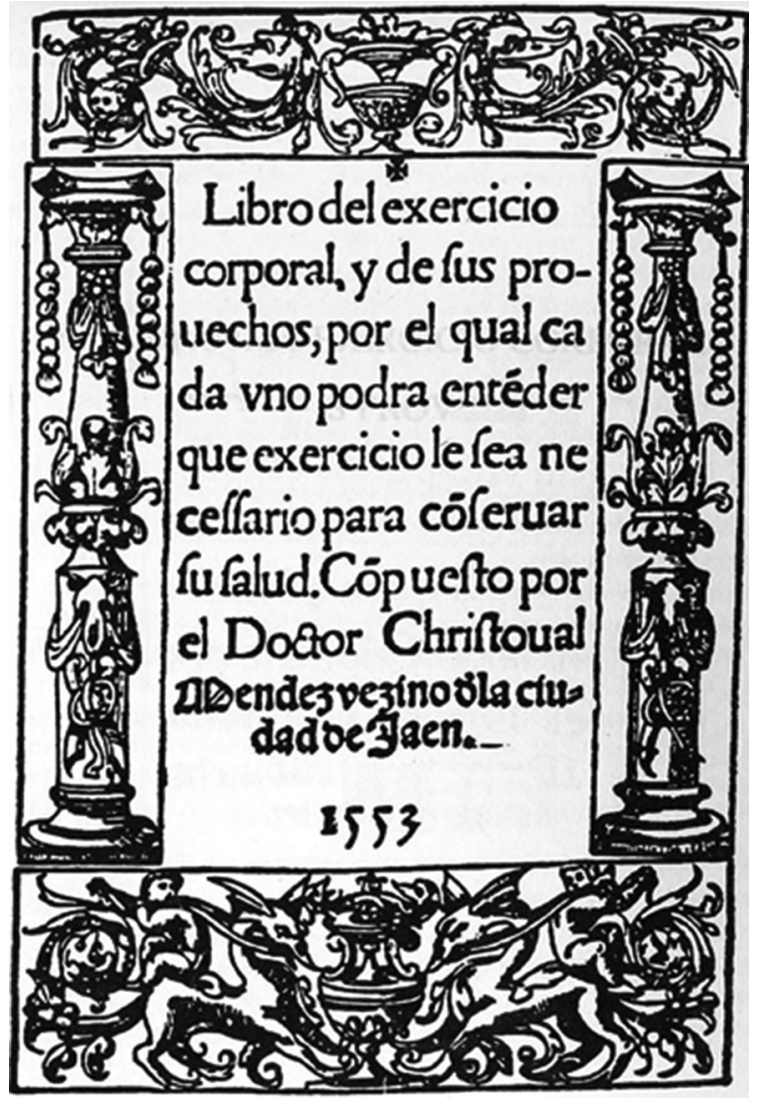

Figure 1. Cover of the "Book of bodily exercise and its benefits", written by Cristóbal Méndez, 1553.

In the first referred case, there is controversy about whether it was a lithotomy or an autopsy, due to the use of the word "open". In the Book of corporal exercise and its benefits (Fig. 1), written in 1553, Cristóbal Méndez mentions the following: "In Mexico, I saw how a boy, not older than five years and son of a very honest man whose name was Villaseñor, was opened and extracted a stone almost the size of an egg; and with no doubt, according to its size, it was formed before the child was born"1. This has been interpreted in some works as a surgical procedure. However, in the critical edition of the book, published by the University of León, Eduardo Álvarez del Palacio claimed that it was not such a procedure but an autopsy, since the author's phrase: "In Mexico, I saw how a boy... was opened...", analyzed in its syntax and expressive form of the time it was written, does not refer, according to the Renaissance terminology, to an operation, but to a case of necropsy. The term "open", in its surgical meaning, is much more modern, whereas in medieval times it was always linked to the word "corpse", which identifies and simplifies the term by reducing it to a synonym of autopsy. For this reason, he concludes that which Cristóbal Méndez observed in
TSecretos de Chirurgia, efpecial de las enfermedades de Morbo galico y Láparones y Mirrarchia, y af'si nifmo la manera como fe cu ran los Indios de llagas y heridas y otras parsio nes en las Indias, muy v til y proucchofo para en Elpaña y otsos muchos fecretos de chirur gia hafta agora no efcriptos.

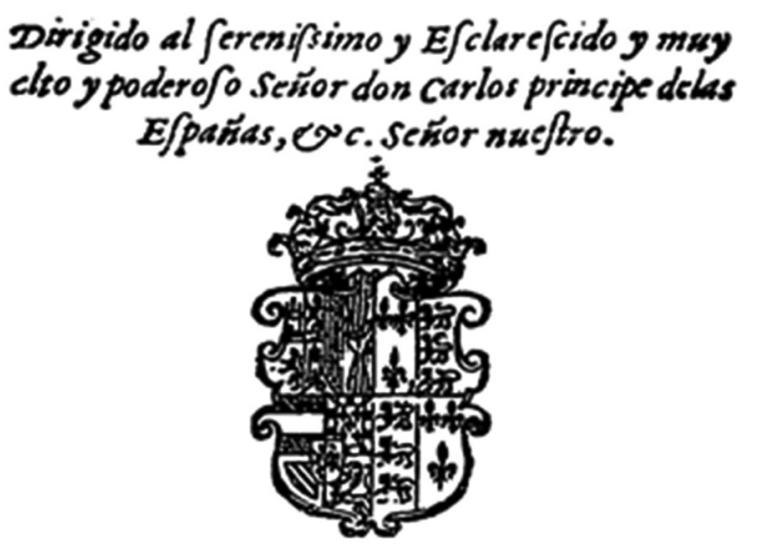

\section{Compaefto por elDolzor Pedrarias de Bewawi des Dezino y ratural dela Ciudad de Tono.}

\section{Impreffo on $V$ alladolid por $F$ rancifo $F$ ermavdes de Cordoua I mprefior de ia M ageftad R eal Co prexille gio, Ta flado a rcal y medio en papel}

Figure 2. Cover of the book "Secretos de chirurgia", by Pedro Arias de Benavides, 1567.

that Mexican boy, "son of a very honest man whose name was Villaseñor," was not a surgical act, but the sad confirmation or discovery of a pediatric lithiasis diagnosis by means of an autopsy ${ }^{4}$.

On the other hand, Pedro Arias de Benavides work is regarded the first publication about a neurosurgical procedure in North America ${ }^{5}$. Arias was a Spanish surgeon who practiced in Mexico in the mid-16 $6^{\text {th }}$ century. When he returned to Spain, he wrote the book Secretos de Chirurgia (Fig. 2), where he narrates that, during his stay in the city of Mexico in 1561, he attended to a 13-year-old boy named Vergara, who had fallen from a church choir and was hit in the head by a gun carriage (wooden frame onto which artillery cannons were mounted). Arias was called upon to assist the boy when he was still unconscious and took care of emergency cure; for the second examination and care of the wound, another surgeon and a doctor were called upon, who simply applied oils and balms to the wound. The next day, when the wound stopped bleeding, he began to remove bone fragments and, on the third day, he removed more bones and a piece 


\section{EMORIA}

SOBRE LA EXTRACCION DE UN CÁLCULO

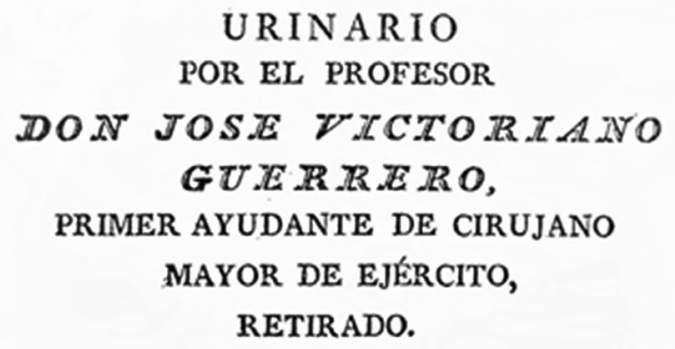

URINARIO

POR EL PROFESOR

DON JOSE VICTORIAANO

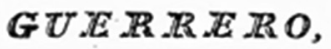

PRIMER AYUDANTE DE CIRUJANO

MAYOR DE EJÉRCITO, RETIRADO.

\begin{abstract}
PRESENTADA AL EXCMÓ. SR. CAPITAN GENERAL DE LA PROVINCIA DE NUEVA GALICIA D. LUIS QUINTANAR, MARISCAL DE CAMPO, Y CABALLERO GRAN CRUZ DE LA IMPERIAI ÓRDEN DE GUADALUPE, EL DIA DE LA PROCLAMACION DE $S$. M. I. EL Sr. D. AGUSTIN. I. ${ }^{\circ}$
\end{abstract}

GUADALAJARA 1822:

IMPRZSA ES LA OFICINA DE DON MARIANO BODRTGEEZ.

Figure 3. Cover of the book "Memoria sobre la extracción de un cálculo urinario", by José Victoriano Guerrero, 1822.

of wood the size of half a fava bean onto which medullary substance was stuck in an amount equivalent to half a chickpea. When the doctor and the surgeon saw the brain substance, they refused to come back to take care of the wound, and since he had been the first one to look after the injured boy, he had to take care of the healing process in the best way possible. Hence, he ordered a plaster based on crushed mallows (probably Malva silvestris L., a plant with emollient and anti-inflammatory properties), fava bean flour, flaxseed, fenugreek (possibly Trigonella foenum-graecum $L$, a medicinal plant with emollient properties), lentils, egg yolks, infancino oil (made of green olives) or rose oil, and chamomile, which he applied onto the wound, and little by little, the signs disappeared. In his book, he also mentions another similar case that occurred to the son of a man named Obregon, who was cured by Dr. Torres².

\section{First surgical news on children}

During a search for historical backgrounds on surgical procedures in Mexican children during the $19^{\text {th }}$ century in the Internet Archive website (https://archive.org) and the Hemeroteca Digital National de México (http:// www.hndm.unam.mx) collections, two documents were found, which are little known and barely cited, where two lithotomies practiced early in the $19^{\text {th }}$ century in Mexican children are described, and which seem to correspond to the first reports of these surgical procedures and constitute the reason for the present work.

\section{Report on the extraction of a urinary calculus}

The first description, entitled Memoria sobre la extracción de un cálculo urinario ${ }^{6}$ (Fig. 3), was written by Professor José Victoriano Guerrero, first assistant surgeon, retired army major, and presented to Hon. General Captain of the Province of Nueva Galicia Don Luis Quintanar, field marshal, and knight of the Grand Cross of the Imperial Order of Guadalupe, on the day of the proclamation of HIM Agustín I. It was published in Guadalajara, on December 12, 1822, by Don Mariano Rodríguez office.

The work begins with a dedication addressed to Agustín I:

Sire.

Those things that are directed to the benefit of humanity, have always interested sensitive hearts, as well as those rare productions in nature that favor the appreciation of illustration, which has placed them with particular care in the best exhibitions of the most cultured powers. Under one and another aspect, can the content of the attached report be considered, which in addition to being so rare, has given life to an unhappy lass, and will return it to those who may be in her state. The love and gratitude professed by Americans to their liberator were more than enough reasons to offer to HIM that what his human heart and a well-formed understanding, should receive with all pleasure, but there is more; when impelled by those feelings alone I was going to present it to $H M$, another object has turned up, whereby I would also like to show my appreciation: The august proclamation of HM that has been solemnized by this capital city today is a new cause for me to proceed. I dedicate it, then, to signify how much my affection and recognition are and that so fairly you are deserving of, without believing it is sufficient to fulfill the greatness of its purpose. I humbly ask you, HIM, accept this present, and may this work be one of the things that decorate the history exhibition of the first Emperor of Mégico [sic]. 
Mister.

José Victoriano Guerrero.

After the dedication, the patient evolution and surgical procedure are described, which are transcribed below:

Two years ago, I was visited by a seventeen-year-old young woman with suppressed menstruation", with less than one year of scant periods. The pale color and languor of the patient persuaded me that the suppression was driven by a chlorotic ailment. I resorted to tonics and recommended the best possible foods her poverty could afford; but as her strength weakened, despite the method I had undertaken, I knew that the main cause was not that which I had announced. Therefore, and I took a new approach, and then she revealed to me that, since four years of age, she suffered from dysuria (urine evacuation with difficulty and pain), and having been told that it was a syphilitic ailment (venereal or Gallic disease), she had feared to reveal it before. I discontinued the previous method, and prescribed the use of demulcent and lukewarm baths, and, in effect, this healing plan derived some intervals of relief.

In spite that, with this regimen, the patient perceived symptoms as being less severe, there was very little progress. Therefore, I examined her with a probe and found a calculus in the bladder, and although I could only touch the portion that appeared in the neck, I was persuaded that, to achieve a radical cure, a lithotomy operation was necessary. I proposed this to the patient, who preferred to continue suffering rather than undergoing the procedure. I prescribed her an ounce of sodium carbonate, in forty-eight papers so that she would take one in the morning and one in the afternoon in a flax-saturated brew, instructing her to give me notice of any occurrences.

After some time, when I thought she might have died, she showed up due to the many ailments she was suffering from, and because walking was becoming even more difficult. At the same time, she said that, since she was increasingly worsening with the carbonate papers, she had discontinued their use. I carried out a new examination, and found the foreign body in a more immediate position. Urine was in a state of strangury (dripping) and the nymphae were extremely prolonged and infiltrated. Since it was not possible to persuade her to continue with

\footnotetext{
María Magdalena Madera, legitimate daughter of Julian Madera and María Josefa Salas, who lives in Guadalajara, at the flowers neighborhood.
}

the carbonate, I used the scheme of combining it with charcoal, and indicated to take it in four ounces of Arabian mucilage in the morning and afternoon. With the continuation of this medicine, the symptoms were increased. The lower limbs became infiltrated, and urination became scarce; but the calculus was advancing. I indicated that, after rubbing her legs with a brush, she should be rubbed with a tincture of mustard and liquid laudanum, in addition to a gastric lavage with flaxseed and opium mucilage, which was continued for some days and somewhat mitigated the pains. However, urine output remained scarce, and the edema increased. Therefore, I only left the previous internal medicine, adding the decoction of dye's madder for use, and increased the carbonate dose to one dragma [sic] per day in four papers. At this time, the pains were tremendous, as well as the expulsion threats. I examined her for the third time and I always thought the operation was indispensable, although not so complicated. I communicated this to the patient, persuading her as best I could and telling her, in order to encourage her, that if she did not comply with this, I would leave and not come back. She only answered to me, begging me to wait a few days, and that if she did not get well, she would undergo the proposed operation. After having indicated the healing plan that was to be followed, I visited her for four days and I did not have to modify anything because I found her in the same state. The fifth day I did not visit her, and the sixth day I was called upon by the mother, who made me see that she was in a terrible state. I attended her home and I found her in such a deplorable situation, that her laments, the extraordinary and useless efforts she made to expel the foreign body, and the tender entreaties for being freed of that torment, moved my compassion to the point that no misfortune has ever touched my heart in such a way. I did not want to miss the opportune occasion that was presenting to me to put into practice the remedy that seemed convenient to me. I examined her more accurately, and found that the calculus had surpassed the neck of the bladder and prostate [sic], that this was an aid that would further facilitate the operation, and that, ultimately, it was mandatory, because the strangury state had turned into ischuria (retention) fifteen hours prior. Everything had a terrible aspect, the sexual parts and immediate structures were in an inflammatory state, and I feared a close fatal outcome if I did not operate promptly as I had thought, and I carried this out as follows. 


\section{Operation $^{\dagger}$}

I placed the patient on her back on a bed, with her lower extremities well separated, putting a small pillow on her hips, for better support, and to raise her a little. I introduced the left index finger into the vagina, smeared with oil, having previously placed a grooved sound in the urethra, until touching the foreign body and affirming it therewith. Satisfied of this first part, I took out the finger and occupied said hand with the sound, and with the right one, I introduced a thin and blunt-tipped scalpel, aided with the index to place it at the beginning of the tube of the probe. Then, placing the finger on the back of the scalpel, I made an incision that came to finish outside, and removing the instruments, I extracted the calculus (which in the original work is attached represented in a print). After half an hour of the incision, the patient was trying to let nature finish her and stop suffering further pain, but finally she was decided. After the operation, I examined the bladder with the chest sound, and I did not find more capacity in it than that represented by the calculus. I applied a cannula as best as possible, supported on a somewhat solid swab greased with cerate. Graduated compresses were applied, as well as an anus $T$ bandage to hold the dressing. The patient was indicated stillness, liquid diet, and a decoction of barley and gum Arabic for use.

The next day, I was received by the patient with the following expressions: "blessed be God, my Lord, I have known what it is like to live without pain." I removed the dressing and found no other novelty but that the patient could not bear the cannula, and had removed it at two hours. I applied an injection of warm milk and placed the swab with cerate, but it was not possible to get the application of the cannula. Internal regimen with demulcents.

She has continued with this simple method since September 7, with no more novelties but urine incontinence due to the omission of the cannula for not bearing it; in fact, in this kind of operations this vice usually remains. On the sixth day of present month, menstruation has been occurring with regularity, and there is almost no cachectic state. Incontinence is so moderate, that the patient, trying to contract the bladder neck, spends a few hours without expelling it. However, this

\footnotetext{
Malignance has tried to diminish his merit, attributing violence on the patient, and intervention of many people, which in addition to being false (since there were no more attendees than the surgeon and the mother, as it can easily be found pout) wouldn't diminish at all (even assuming it) the glory of having timely performed the operation, and depriving death of a victim that was nearly under its domain.
}

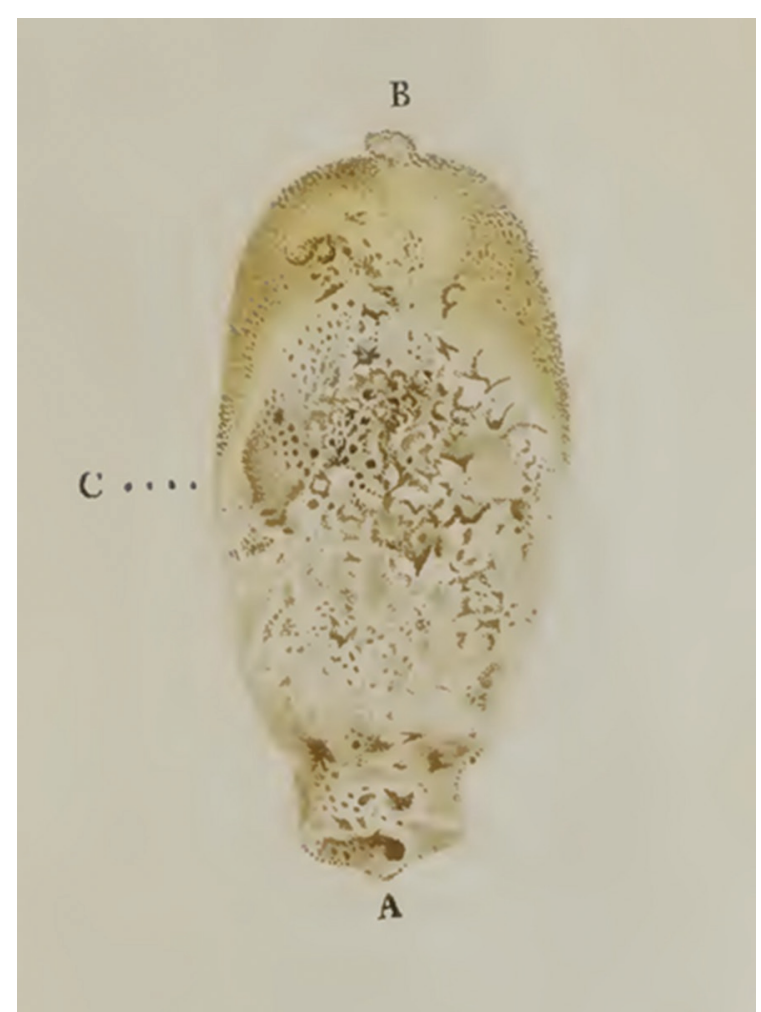

Figure 4. Image of the calculus extracted by José Victoriano Guerrero, 1822.

action bothers her because she says that it tires her. Being in a horizontal position, the urine is deposited in the bladder in the quantity of barely one quarter, and she expels it with attempts, which proves that the bladder sphincter suffered no harm, and that there is hope that, over time, it will acquire its natural resilience ${ }^{\ddagger}$. Guadalajara, December 12, 1822.

Explanation of the print. A. Calculus portion, surrounded by the bladder neck. B. Part corresponding to the fundus of thereof. C. View from its anterior face. Its weight just after extraction was about nearly an ounce and a half. Its shape has varied because of the much friction it has undergone; it was rougher, and the neck was more bulky, the loose portions belong to it (Fig. 4).

\section{Bladder stone removal operation according to the lateralized method}

The second work is entitled Operación de talla según el método lateralizado, por el Dr. Jecker, written by Dr. Luis Jecker and was published in the first issue of the first volume of Periódico de la Academia de Medicina de Mégico in $1836^{7}$ (Fig. 5). Below, the article is transcribed:

Pharmacy Professor, Mr. Juan José de Arezpacochaga, provides as many medicines as needed free of charge. 


\section{OPERACTON DE TALLA SEGUN EL METODO lateralizado, por el Dr. Feeker.}

IAs onfermedades do las vias uri- $\mid$ parto, dando gritos agudos; entónces narias son generalmente comunes on salian algunas gotas de agua por el Ḿggico; sin embargo, el cálculo 6 pie- meato urinario, las cuales se suspon. dra en la vegiga es bastanto raro. dian repentinamente; al mismo tiempo Resulta de ahí que las ocasiones do el pene muy crecido para su edad, se practicar la operacion que liberta á hinchaba se endurecia, se torcia, pa. los enfermos de este mal no se pro- rocia entrar en ereccion, $a$ la vez que sentan con frecuencia. Es pues una estaba estirado por una contraccion casualidadbastante extraordinaria que convulsiva de los ischio-cavernosos, y dos operacionos do talla bayan sido los testes ostirados fuertemente por practicadas en seguida con un inter- arriba por la de los cremasteres; al valo de quince á veinte dias: habien- mismo tiempo salia el intestino recto $\begin{array}{ll}\text { do tenido las dos un resultado favora- } & \text { mismo tiempo salia el intestino } \\ \text { cosa de dos } \delta \text { tres pulgadas. }\end{array}$ ble, empezarémos por la primera, que A pesar de estos padecimientos, el segun los datos que tenemos, parece estómago se mantenia bueno, y este ser la primera tambien que se ha ejo- niño tenia salud en ol resto do su cutado en Mégico.

Un niño de cinco años padecia ha- Se sospecho muy breve quo esto cia mas do un año cada vez que ori síntomas anunciaban una piedra en naba: los dolores fuerou constante- la vegiga; se le sonde6, y la piedra mente en aumento, y en los últimos fué encontrada y reconocida con bas. meses que precedieron á la operacion, tante facilidad esta primera vez y las ved aquí cómo se le puedo figurar en siguientes hasta el dia que se deter-

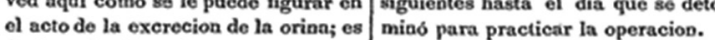
decir, cada diez minutos, que ora to- Este dia todo estaba dispuesto pado el intervalo que tenia libre de es- ra proceder $\mathbf{a}$ ella: el enfermito ligado ta necesidad. Tan pronto como la sen. y puesto en la posicion debida, se intia, doblaba el cuerpo, cogiendo el trodujo prima penis con una como, penis con una mano, con la otra so ta exploratriz que habia servido en agarraba do las enaguas de su madre, las ocasiones anteriores, despues un $\sigma$ de la orilla de un mueblo, la vegi- cateter acanalado do acero, y á pe. ga se contraia, y él agregaba a estas sar de las mas minuciosas indaga contracciones las do los músculos del ciones, bastante prolongadas, fué pro. abdomen y del diafragma como on ol ciso abandonar para otro dia la opo-

I.

Figure 5. Article "Operación de talla según el método lateralizado, por el Dr. Jecker", published in Periódico de la Academia de Medicina de Mégico first number, 1836.

Urinary tract diseases are generally common in Mégico [sic]; however, the calculus or stone in the bladder is quite rare. It turns out that opportunities for practicing the operation that frees patients from this ailment do not occur frequently. It is therefore a rather extraordinary coincidence that two bladder stone removal operations have been practiced immediately, with an interval of fifteen to twenty days: having both had a favorable result, we will begin with the first one, which according to the data we have, it also appears to be the first one that has been executed in Mégico.

A five-year-old boy suffered since more than one year ago every time he urinated. The pain was constantly increasing and, in the last months that preceded the operation, this is how he can be pictured in the act of urine excretion; that is, every ten minutes, which was the entire interval he was free of this need. As soon as he felt the urge, he would bend the body holding the penis with one hand, and with the other he clung to his mother's petticoat, or to the edge of a piece of furniture. The bladder contracted, and he added to these contractions those of the abdomen muscles and the diaphragm as in child delivery, screaming out high-pitched sounds. Then, some drops of water came out through the urinary meatus, which suddenly stopped. At the same time, the penis, which was too developed for the boy's age, swelled, hardened and twisted as if it was entering into erection. At the same time, it was stretched by a convulsive contraction of the ischiocavernosus muscles, and the testes strongly stretched over the cremaster muscles; simultaneously, the rectum was protruded two or three inches.

Despite these ailments, the stomach remained in good shape, and the boy was healthy in the rest of its constitution and quite robust.

Very briefly, these symptoms were suspected to announce a stone in the bladder; he was surveyed and the stone was found and recognized quite easily this first time and the ensuing ones until the day it was decided to practice the operation.

This day, everything was ready to proceed to it: the young patient was tied up and placed in the right position. First, the exploring silver sound that had served on previous occasions was introduced, then a grooved steel catheter, and despite the most thorough and quite prolonged inquiries, abandoning the operation for another day was necessary, with the doctor adhering to the formal precept of the art in this rare circumstance.

Ten days later, Dr. Jecker, who again had confirmed the presence of the foreign body, returned to his first determination, and operated the boy according to the lateralized method and Brother Cosme procedure, in the presence of his colleagues Sollier, Escobedo, Morón, Blaquière, and several students of the Anatomy course. The operation was rather laborious. Since prior to the first incision the child was very unruly; he moved, shouted and made exertions, which caused the protrusion of the rectum, but with such force, that its reduction was very difficult, and its permanence even worse. It was maybe necessary to proceed to this reduction ten or twelve times before being able to open the bladder neck. The same inconvenience was reproduced and even more often when the tongs were introduced. It should have been witnessed to have an idea of the difficulties that this accident opposed to the surgeon's movements and to the most important circumstances of the operation. The situation was such, that after many attempts, fearing serious consecutive accidents, leaving for the moment the continuation of the operation was necessary, and deferring it for some days, which is referred to as performing the operation in two times.

The patient was untied, put on his bed, legs halfshrunk. He was subjected to a strict diet, long and 
renewed baths on the same day, emollient and abundant beverages. The next night he slept, with no serious accident occurring. He experienced no chills and no pain, only the pulse took an acceleration that reached one hundred and sixty-eight beats per minute, and lasted several days in this same state. On the other hand, since the young patient had no need to make efforts to urinate, the rectum did not stick out in a single occasion even in the second operation. This is the case of the axiom: Sublata causa, tollitur effectus.

Eight days after the first operation, he came back for the second one; the child was placed as in the first procedure. As previously mentioned, the rectum would not stand in the middle anymore, and it was easy to enlarge the wound in the bladder neck, which was already beginning to close. Dr. Jecker promptly extracted a lime urate calculus, about the size of a walnut, of medium consistency, some fragments of which remained in the bladder, but were rinsed off by means of some mauve water lotions.

The consequences of this second operation were the same as in the first one. Less than fifteen days later, the boy was good and healthy.

\section{Commentary}

The two publications presented in this paper appear to be the first records of surgical procedures in children of Mexico during the $19^{\text {th }}$ century, as Dr. Jecker points out in his work, since the review of the medical literature of the time, as well as the most recent one, do not register any surgical procedure in children. For example, the work Estado actual y progresos de la cirugía en México (Current state and advances of surgery in Mexico) (since the year of 1810 in which Independence began to date), written by Dr. Julián Villarreal on behalf of the National Academy of Medicine for the Scientific and Artistic Contest of the Centennial in $1911^{8}$, does not mention them. However, when he refers to Periódico de la Academia Nacional de Medicina de Mègico, he points out that, on page 33 of number 2 , of the first volume of 1836, there is an observation about the bladder stone removal procedure according to the bilateral method after lithotripsy in a 52-year-old male, written by Dr. Luis Blaquiere, but he fails to mention Dr. Jecker's work, published one month earlier in the same journal. However, it is fair to mention that, in the book La cirugía mexicana del siglo XIX (Mexican Surgery of the $19^{\text {th }}$ century), Dr. Rafael Heliodo Valle lists Dr. Jecker's work, but he does not mention that it was in a boy or describe the procedure ${ }^{9}$.

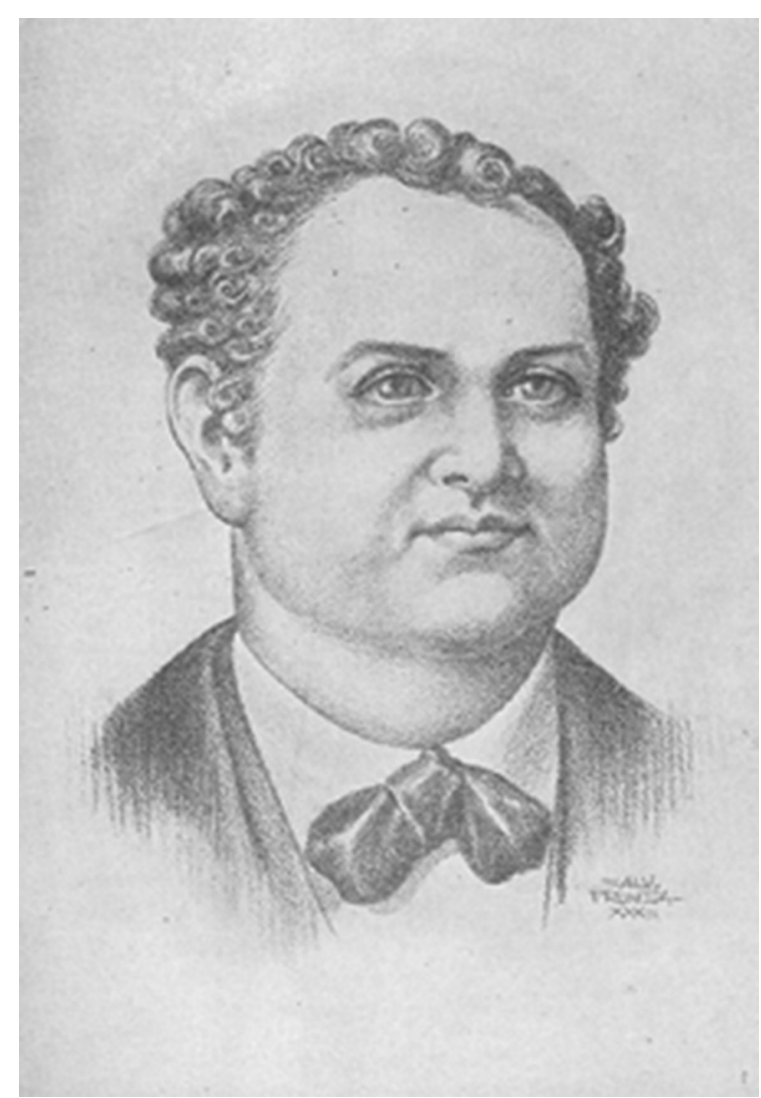

Figure 6. Dr. Luis Jecker, first anatomy professor at the Establishment of Medical Sciences, created in 1833 (Taken from: El Establecimiento de Ciencias Médicas y sus primeros catedráticos. México, Departamento Autónomo de Prensa y Publicidad, DAAP, 1939.

Little is known about José Victoriano Guerrero, but like other surgeons of his time, he also treated other ailments, which can be confirmed with some ads addressed to the people of Guadalajara in 1833 about a new curative method for epidemic cholera ${ }^{10,11}$. In addition, it is important noting that his surgical report is not academic in nature, but it represents the description of a feat: saving the life of a young woman sentenced to die in an era when there were no anesthetics or aseptic and antiseptic techniques, an action that Guerrero himself considered worthy of printing as a present to Mexican emperor Augustin I, to celebrate his ascension to the throne.

In relation to Dr. Luis Jecker, there is more information. It should be noted that in Periódico de la Academia he published other works, both medical and surgical, among which Rara conformación accidental de las partes genitourinarias de una muger (Rare accidental conformation of the genitourinary parts of a woman) ${ }^{12}$ and Sobre la neumonía en los niños (About pneumonia in children) stand out, which shows the extent of its clinical activity, in addition to the fact that the work on pneumonia is the 
first report about the treatment of this disease in Mexican children. Dr. Jecker, of Swiss origin, but French-nationalized (Fig. 6), registered his title at the Protomedicato on January 14,1831 , and although his name appears on the surgeon's list, it is preceded by the title of doctor, which suggests that his studies were not only in surgery but also in medicine ${ }^{14}$. He was the first anatomy professor at the Establishment of Medical Sciences, replacing Mr. Guillermo Chayne, who did not take office. In his book Memorias de mis tiempos, Guillermo Prieto, the popular Fidel, says: "I see Jecker with his blond hair, his plump and padded hands, his blue eyes, his obese body, but ready and with a certain shopkeeper's self-confidence. But in the operations, he was transformed, his hand was extremely light, his scalpel seemed to have an intelligence of its own; for him, the human body was like crystal"15. Similarly, Manuel Payno refers to Dr. Jecker: "He had large hands, with short, fat fingers, like the hands of a muleteer, but when he performed an operation, the polished hands of a lady were not softer or more delicate. In those days, anesthetics were not known, and patients had to suffer, as true martyrs, an operation lasting 10, 20 or 40 minutes. Jecker's ability and skill almost replaced chloroform, he performed difficult healing procedures and operations in cases, as physicians coldly say, that were truly desperate. His fame flew throughout the Republic; to the rich, he charged enormous bills; to the poor, he healed for nothing, and sometimes would spare some money for medications ${ }^{16}$. He was holy in his charity, in his patience and in his love for the poor. This doctor can be called without exaggeration the father of surgery in Mexico"15. He died in Paris in 1839, where he went to settle after leaving the country because of a Law establishing that the French should leave the Republic, published on December 1, $1838^{17}$.

To conclude, it should also be noted that Francesco Antommarchi, Napoleon's physician, who took care of performing his autopsy and his funeral mask, arrived to our country in 1835 and worked as a surgeon in Mexico, Durango, Guadalajara and San Luis Potosí, where he performed numerous ophthalmic surgeries, and although there is no description of his operations, Doctors Fernando Serrano and Pascual Agraz testified to his surgical work and listed his operations in Guadalajara, where, according to their records, on October 13,1835 , he practiced a hypogastric bladder stone extraction on a child of Mr. Mariano Brambila, and on the $17^{\text {th }}$ of the same month, he removed a lipia from the outer corner of the eye of another child ${ }^{18}$.

\section{Ethical responsibilities}

Protection of people and animals. The authors declare that no experiments have been conducted on humans or animals for this research.

Confidentiality of data. The authors declare that no patient data appear in this article.

Right to privacy and informed consent. The authors declare that no patient appear in this article.

\section{Funding}

There was no funding.

\section{Conflict of interests}

There are no conflicts of interests.

\section{References}

1. Méndez C. Libro del ejercicio y de sus provechos. Sevilla: Maestro Grigorio de la Torre; 1553.

2. Arias de Benavides P. Secretos de chirurgia. Valladolid: Francisco Fernández de Córdova; 1567.

3. Rodríguez-Paz CA, Carreón-Bringas RM. Algunos aspectos sobre la cirugía pediátrica en el siglo XIX en México. Bol Med Hosp Infant Mex. 2004;61:352-6.

4. Méndez C. Libro del ejercicio corporal y de sus provechos. Estudio, edición y notas de Eduardo Álvarez del Palacio. León: Universidad de León, Secretariado de Publicaciones; 1996.

5. Chico-Ponce de León F, Goodrich JT, Tutino M, Gordon C. First published record of a neurosurgical procedure on the North American Continent, Mexico City, by Pedro Arias de Benavides, 1561: Secretos de Chirurgia, Valladolid, Spain, 1567. Neurosurgery. 2000;47:216-22.

6. Guerrero JV. Memoria sobre la extracción de un cálculo urinario. Guadalajara: Oficina de don Mariano Rodríguez; 1822.

7. Jecker L. Operación de talla según el método lateralizado, por el Dr. Jecker. Periódico de la Academia de Medicina de Mégico. 1836; 1:9-10.

8. Villarreal J. Estado actual de la cirugía en México. Concurso Científico y Artístico del Centenario. México: Tip. de la viuda de F. Díaz de León, Sucs; 1911.

9. Valle RH. La cirugía mexicana del siglo XIX. México: Tipográfica Sag; 1942. p. 91.

10. López JA, Guerrero V. Aviso al pueblo. Método curativo. Guadalajara: Imprenta del Supremo Gobierno; 1833.

11. Guerrero V, López A, Moreno I, Jurado I. Nuevo método curativo y observaciones hechas sobre la cólera epidémica. Guadalajara: Imprenta del C. Urbano Sanromán; 1833.

12. Jecker $L$. Rara conformación accidental de las partes genitourinarias de una muger. Periódico de la Academia de Medicina de Mégico. 1836; 1:114-6.

13. Jecker $L$. Sobre la neumonía de los niños. Periódico de la Academia de Medicina de Mégico. 1836;1:345-55.

14. Bandera B. El Dr. don Luis Jecker. En: Centenario de la fundación del Establecimiento de Ciencias Médicas 1833-1933. Contribución de la Academia Nacional de Medicina. México: Departamento Autónomo de Prensa y Publicidad; 1938. p. 55-69.

15. Prieto G (Fidel). Memorias de mis tiempos 1828 a 1840. México: Librería de la Vda. de C. Bouret; 1906. p. 198-9; 300-1.

16. Payno M. Reseña histórica de la invasión en México. México: Imprenta del Gobierno, en el ex-Arzobispado; 1898. p. 17-8.

17. Dublán M, Lozano JM. Legislación mexicana o edición completa de las disposiciones legislativas expedidas desde la Independencia de la república, Tomo III. México: Imprenta del Comercio, a cargo de Dublán y Lozano, Hijos; 1876. p. 566-7.

18. García de Alba GJ. El Dr. Antommarchi. ¿En Guadalajara? Estudios Históricos. 1981;III Época (17):15-23. 